in a substantial sum was taken at one of the sessions of the day, for the re-establishment of the Doeveren church in the Netherlands, the Scholte church, which was completely destroyed during World War II.

This is the same church at Utrecht, from which, in 1907, the Misses Sarah and Hannah Nollen, of Des Moines, obtained the pulpit from which their grandfather had preached before coming to America, and brought to the Iowa Historical department on loan, until provision was recently made for its installation in the new museum at Central college at Pella.

\title{
PETERSON HEADS HISTORICAL SOCIETY
}

The board of curators of the State Historical society at Iowa City, at their mid-summer meeting, elected Dr. William J. Peterson superintendent of the society. He had served for the past seventeen years as a research associate, and now succeeds Miss Ethyl Martin as superintendent. As a writer of ability his articles have appeared in the Palimpsest, the Iowa Journal of History and Politics and other publications of the society, also teaching Iowa history in the State University of Iowa. Dr. Peterson has lectured extensively throughout Iowa to schools, clubs, patriotic, religious and professional organizations and historical societies. The new superintendent was born at Dubuque, where he graduated from Dubuque high school and the University of Dubuque. He received his doctor's degree in history from the State University in 1930.

\section{DEATH CLAIMS DONOR OF WAR POSTERS}

The death of William P. Kerwin, president of Kerwin's Inc., at Waterloo, occured September 7, 1947, from the effects of a stroke suffered the previous Friday. For 58 years he has been in the clothing business, first with his father and later became president of the company which has stores in Oelwein, Waverly and Cedar Falls.

In World War I he served overseas with the Eightyeighth U. S. division as a Knights of Columbus divisional 
secretary. Upon his return he devoted some time to the arranging of exhibits of interesting war relics and posters of European countries engaging in the conflict. This wonderful collection of posters were mounted in suitable manner behind glass in metal frames, and in 1929 were presented by Mr. Kerwin to the Iowa Department of History \& Archives for display in World War I room, where they have since attracted a great deal of attention. They include 63 foreign war posters of France, Great Britain, Germany, Italy, Russia, Belgium and Poland.

A translation of the inscriptions upon other than the British posters was made by Professor LeCoq, of Drake University, Des Moines. Mr. Kerwin was very active in many community enterprises and patriotic activities, including work upon the draft board in World War II.

\section{PASSING OF A FORMER SLAVE}

Iowa has few living evidences of the touch we once had with the Civil war era. In recent decades the last veterans wearing either the blue or the gray have rapidly gone to their reward, and but few yet remain among the living.

Another group, not so large, identified with the sixties and prewar days, were the few ex-slaves, who found homes in this state; but nearly all, if not every one, has likewise gone. Possibly the last such in Iowa passed away in October last, at Oskaloosa, in the person of Charles Adams, aged 102, colored and born in slavery in Virginia in 1845.

He was freed when about ten years old, and had been making his home in Oskaloosa the past seventy-five years, where he was steadily employed in one of the local institutions. Records are inadequate often times for proof of the exact age of the elderly, white or black; but even a shading down of the age claimed for Mr. Adams, his touch with the Civil war era is not to be questioned, and that he was one of the last of that circle to remain among the living in Iowa until very recently 
Copyright of Annals of Iowa is the property of State of Iowa, by \& through the State Historical Society of Iowa and its content may not be copied or emailed to multiple sites or posted to a listserv without the copyright holder's express written permission. However, users may print, download, or email articles for individual use. 